\title{
PERAN PEMERINTAH DALAM PENGELOLAAN LAHAN PEMAKAMAN UMUM DI KOTA MAKASSAR
}

\author{
A.Nukmawati ${ }^{1}$, Mappamiring $^{2}$, Ansyari Mone ${ }^{3}$ \\ 1) Jurusan Ilmu Administrasi Negara Fisipol Unismuh \\ 2) Jurusan Ilmu Administrasi Negara Fisipol Unismuh \\ 3) Jurusan Ilmu Administrasi Negara Fisipol Unismuh
}

\begin{abstract}
The objective of this study is to find out the government role towards the management of public cemetery land in Makassar. The type of the research is descriptive qualitative with phenomenological research type. The data were collected through interview, observation and documentation. The data were analyzed through data reduction, data display and conclusion. The findings of the research indicate that the role of the government as the regulator (Environmental Service) of Makassar city in managing the public funeral is not optimal due to a number of obstacles in its implementation process. The role of the government as the facilitator land provider concept is that not only do they serve as public service institution but also in a democratic society they have a main role as facilities and infrastructures providers.

Key word: Role, government, funeral land management.
\end{abstract}

\begin{abstract}
ABSTRAK
Penelitian ini bertujuan untuk mengetahui peran pemerintah dalam pengelolaan lahan pemakaman umum di kota Makassar. Jenis penelitian yang digunakan dalam penelitian ini adalah deskriptif kualitatif dan tipe yang digunakan dalam penelitian adalah fenomenologis. Teknik pengumpulan data yang digunakan peneliti adalah wawancara, observasi dan dokumentasi. Teknik analisis data yang digunakan adalah Reduksi data, Penyajian data, dan kesimpulan. Hasil penelitian ini menunjukkan bahwa peran pemerintah sebagai regulator (Dinas Lingkungan Hidup) kota Makassar dalam mengelola pemakaman umum masih belum maksimal sebab dalam proses pelaksanaanya masih memiliki banyak hambatan dan kendala. Peran pemerintah sebagai fasilitator konsep penyedia lahan tidak sekedar sebagai institusi pelayanan masyarakat tetapi dalam masyarakat yang demokrasi memiliki peran pokok yaitu penyedia fasilitas dan sarana prasarana.
\end{abstract}

Kata kunci: Peran, Pemerintah, Pengelolaan lahan pemakaman. 


\section{PENDAHULUAN}

Indonesia merupakan Negara yang wilayahnya terbagi atas daerahdaerah provinsi yang mempunyai taman pemakaman umum (TPU) yang sempit. Karena semakin besarnya angka kematian warga Indonesia dan jumlah populasi penduduk Indonesia.

Kota Makassar merupakan ibu kota Provinsi Sulawesi Selatan dengan jumlah penduduk setiap tahunnya mengalami peningkatan, Salah satu sarana fasilitas sosial adalah lahan pemakaman. Tidak dapat dipungkiri, lahan pemakaman jenazah sangatlah dibutuhkan bagi manusia.

Pemerintah Kota Makassar dalam hal ini Dinas lingkungan hidup Kota Makassar sesuai tugas dan fungsi merencanakan, mengkoordinasikan, membina, mengawasi dan mengendalikan serta mengevaluasi di bidang pelayanan pemakaman, bidang pembangunan dan Pemeliharaan makam serta pengendalian makam di Kota Makassar. Sehingga dikeluarkannya Peraturan Daerah Nomor 8 Tahun 2009 tentang pelayanan pemakaman dan pengabuan mayat di kota Makassar yang menerapakan bahwa pemakaman dan pengabuan mayat yang merupakan hak dasar bagi penduduk kota Makassar sehingga pelayanan pemakaman dan pengabuan mayat perlu diarahkan dalam rangka untuk memenuhi kebutuhan masyarakat. sistem sewa tanah makam sebagai salah satu langkah untuk melangsungkan penguburan jenazah ditengah-tengah lahan pemakaman yang sangat terbatas.

Pertumbuhan penduduk yang semakin meningkat menimbulkan kebutuhan terhadap lahan semakin meningkat pula. Hal ini dapat dilihat pada fenomena semakin banyaknya perumahan yang berada di pinggiran kota. Adanya pembukaan lahan permukiman baru menyebabkan pertumbuhan penduduk baik penduduk baru sebagai pendatang dan penduduk lama yang telah tinggal sebelum adanya permukiman baru. Sehingga menyebabkan peningkatan kebutuhan ruang baik sebagai ruang terbuka maupun ruang terbangun. Sedangkan kenyataannya dalam pembangunan perumahan 
sebagai permukiman baru terutama skala besar yang seharusnya mempunyai fasilitas lahan pemakaman sebagai salah satu bentuk ruang terbuka hampir setiap perumahan tidak menyediakannya.

Arahan penataan pemakaman umum di Kota Makassar mempunyai lima alasan utama yaitu pertama, sempitnya lahan pemakaman di kota Makassar akibat lahan pemakaman sudah penuh, kedua, Adanya kecenderungan pembangunan perumahan ke daerah pinggiran kota sehingga terdapat suatu peluang ketersediaan lahan yang mencukupi untuk pemenuhan kebutuhan pengembangan pemakaman dengan konsep taman di lingkungan perumahan. Sehingga diperlukan suatu arahan penataan pemakaman yang sesuai, ketiga, Adanya permasalahan di lingkungan perumahan lain karena tidak menyediakan lahan pemakaman yang berfungsi sebagai fasilitas sosial, sehingga penghuninya mengalami kesulitan apabila akan melakukan proses pemakaman, keempat, Sempitnya penyediaan lahan pemakaman umum sehingga mempengaruhi kebutuhan lahan berupa jumlah penduduk dan angka kematian, kelima, Makassar mulai kesulitan mencari lahan untuk kompleks pemakaman dan perkuburan baru di kota ini.

Menurut Soerjono Soekanto (2006), peran adalah merupakan aspek dinamis kedudukan (status). Apabila seseorang melaksanakan hak dan kewajibannya sesuai dengan kedudukannya, maka ia menjalankan suatu peranan.

Menurut Nurcholis (2007) peran adalah serangkaian rumusan yang membatasi perilaku-perilaku yang diharapkan dari pemegang kedudukan tertentu misalnya dalam keluarga, perilaku ibu dalam keluarga diharapkan bisa memberi anjuran, memberi penilaian, memberi sangsi dan lain-lain. Seiring dengan pilar utama negara hukum yaitu asas legalitas (legaliteitsbeginsel atau het begin sel van wetmatigheid van bestuur), maka berdasarkan prinsip ini tersirat bahwa peran pemerintahan berasal dari peraturan perundang-undangan.

Peranan adalah suatu konsep yang dipakai sosiologi untuk 
mengetahui pola tingkah laku yang teratur dan relatif bebas dari orangorang tertentu yang kebetulan menduduki berbagai posisi dan menunjukkan tingkah laku yang sesuai dengan tuntutan peranan yang dilakukannya. Levinson dalam Sunarno (2008),

Peranan merupakan aspek yang dinamis dari status atau aspek fungsional dari kedudukan. Bila seseorsng melaksanakan hak dan kewajibannya sesuai dengan kedudukannya, berarti orang tersebut telah menjalankan perannya, jadi peran yang dimaksud adalah tingkah laku yang diharapkan dari seseorang yang mempunyai kedudukan. Ndraha (2003)

Pengertian pemerintah dilihat dari sifatnya yaitu pemerintah dalam arti luas meliputi seluruh kekuasaan yaitu kekuasaan legislatif, kekuasaan eksekutif, dan kekuasaan yudikatif. Sedangkan pemerintah dalam arti sempit hanya meliputi cabang kekuasaan eksekutif saja. (W. Riawan Tjandra 2005).

Menurut Arif (Fadilah, 2014), peran pemerintah lebih sebagai pelayanan masyarakat (customerdriven, government) fasiltator dan motivator yang tidak bertujuan memperoleh keuntungan atau profit, sehingga haruslah "meeting needs of the costumer, not the bureaucrary) dimana lebih mementingkan terpenuhinya kepuasan pelanggan (coustumer) dan bukan memenuhi apa yang menjadi kemauan birokrasi itu sendiri.

Dalam rangka pembangunan nasional, peran pemerintah tidak hanya melaksanakan tugas umum pembangunan melainkan yaitu mengarahkan, menggerakkan dan mengendalikan pembangunan secara lancar, serta meningkatkan peran aktif masyarakat dalam pembangunan. Arifuddin (Rizal 2014).

Menurut Dougherty dan Pritchard dalam Bauer (2003), Teori peran pemerintah merupakan suatu kerangka konseptual dalam studi perilaku di dalam organisasi. Mereka menyatakan bahwa peran itu "melibatkan pola penciptaan produk sebagai lawan dari perilaku atau tindakan”. Lebih lanjut, Dougherty dan Pritchard mengemukakan bahwa 
relevansi suatu peran itu akan bergantung pada penekanan peran tersebut oleh para penilai dan pengamat terhadap produk dan outcome yang dihasilkan

\section{Rumusan Kriteria Penyediaan} Lahan Pemakaman Menurut Mulyana (1994), rumusan kriteria penyediaan lahan pemakaman yaitu pengaturan lokasi pemakaman dalam konteks tata ruang kota dan pengaturan lokasi pemakaman berdasarkan kedekatannya dengan elemen guna lahan lainnya.

Prinsip Penataan Tempat Pemakaman Umum Menurut Hutauruk (2010), komponen penataan kawasan TPU terdiri dari petak makam, elemen vegetasi, jalur pejalan kaki, jalur kendaraan dan tempat parkir, plaza dan ruang terbuka, gedung pengelola TPU, elemen penanda, lampu penerangan, tempat duduk, gerbang, pagar, dan jaringan utilitas. Setiap komponen harus ditata sesuai dengan variabel penataan yang ada pada komponen tersebut seperti luas, bentuk, ukuran, jarak, letak, material permukaan dan lain-lain. Hal ini perlu diperhatikan karena dengan fasilitas yang baik maka TPU dapat optimal sebagai salah satu elemen sarana ruang terbuka hijau yang dapat dimanfaatkan selain untuk kepentingan pemakaman (sosial), tetapi juga untuk tempat rekreasi agar menghilangkan kesan mistis yang selama ini masyarakat rasakan. Fasilitas-fasilitas tersebut harus tersedia sebagai upaya dalam pelayanan kepada masyarakat pengguna sarana TPU.

Tujuan Pengelolaan lahan bertujuan untuk pembangunan dan menyangkut pengaturan kembali penggunaan, pemanfaatan, pemilikan, dan penguasaan tanah (landreform) sejalan dengan penatagunaan tanah. Selain itu juga bertujuan menghindari diskriminasi dan (arbitrariness) mencegah pemerkayaan diri melalui tindakan pemerintah.

\section{METODE PENELITIAN}

Penelitian ini dilaksanakan selama selama 2 bulan. Penelitian ini dilakukan pada tanggal 11 Februari s/d 11 April 2017. Adapun lokasi penelitian ini yaitu di Kantor 
dinas lingkungan hidup Kota Makassar.

Jenis Penelitian Berdasarkan kerangka teori dan kerangka penelitian ini yang telah dikemukakan sebelumnya, maka jenis penelitian ini yaitu penelitian kualitatif yaitu metode penelitian yang digunakan untuk meneliti kondisi objektif dengan menggambarkan situasi-situasi atau kejadian-kejadian secara sistematis, taksual dan akurat mengenai penyediaan lahan pemakaman umum di Kota Makassar.

Tipe penelitian ini adalah penelitian studi kasus yaitu suatu penelitian yang berusaha memberikan penjelasan dan gambaran berbagai macam data yang telah di kumpulkan dari objek penelitian yang berkaitan dengan penyediaan lahan pemakaman umum di Kota Makassar.

Data bersumber dari data primer dan sekunder. Dengan informan berjumlah 10 orang.

Teknik pengumpulan data merupakan langkah yang paling strategis dalam penelitian, karena tujuan utama dalam penelitian adalah mendapatkan data, tanpa mengetahui tehnik pengumpulan data, maka peneliti akan mendapatkan data yang memenuhi standar data yang ditetapkan.

Teknik pengumpulan data yang digunakan adalah observasi, wawancara dan dokumentasi. Teknik Analisis Data yang digunakan adalah Data reduction (reduksi data), Data display (penyajian data),

Conclusion draing/verification (penarikan kesimpulan dan verifikasi).

\section{HASIL DAN PEMBAHASAN}

Sebagai kota yang memiliki pemakaman umum yakni pemakaman islam Dadi, islam Beroangin, islam Paropo, islam Sudiang raya, Kristen panaikang dan pemakaman Kristen Pannara kota Makassar yang memiliki lahan yang cukup sempit akibat pemakaman yang sudah penuh kecuali pemakaman islam Sudiang raya yang masih mempunyai lahan pemakaman yang masih bisa menampung mayat kedepannya.

Berdasarkan hasil penelitian yang dilakukan oleh peneliti bahwa 
peran pemerintah sebagai regulator (Dinas Lingkungan Hidup) kota Makassar dalam mengelolah pemakaman umum masih belum maksimal karena dalam proses pelaksanaanya tidak masih memiliki banyak hambatan dan kendala.

Dari hasil wawancara peneliti menunjukan bahwa terdapat beberapa kendala diantaranya kurangnya ketersediaan lahan yang ada, diakibatkan semakin sempitnya lahan pada wilayah perkotaan di kota Makassar selain dari pada itu dari hasil wawancara diatas mengatakan bahwa lahan yang bisa dipergunakan hanya terdapat pada wilayah pinggiran kota hal ini menjadi penghambat warga menuju ketempat pemakaman, Dari tanggapan pemerintah hanya hal inilah yang menjadi suatu solusi yang dapat diberikan kepada masyarakat wilayah kota Makassar. Kita melihat bahwa dari tahun ketahun jumlah penduduk kota makassar semakin meningkat dan luas wilayah pada kota Makassar dari tahun ketahun semakin sempit hal ini dipengaruhi oleh urbanisasi, dari permasalahan ini jumlah penduduk dan wilayah perkotaaan tidak sebanding dengan rasio yang dibutuhkan antara jumlah penduduk dengan luas wilayah.

Berdasarkan olahan data yang diperoleh menunjukan bahwa semua wilayah pemakaman yang ada pada wilayah kota Makassar baik pemakaman islam maupun kristen penuh dari data ini menunjukan pemerintah segera mengambil langkah dan arah kebijakan yang tepat supaya pemakaman yang penuh dapat segera diatasi lewat dengan kebijakan dan solusi yang tepat dalam menangani permasalahan ini.

Berdasarkan hasil wawancara dengan kepala UPTD pemakaman tentang peran pemerintah dalam penyediaan lahan pemakaman yang terkait dengan penyediaan lahan di mana pemerintah sudah menyediakan lahan pemakaman yang di sediakan namun penyediaan lahan ini sangat terbatas dengan melihat angka kematian setiap harinya mencapai 20 orang. Dalam hal ini9 berikut data yang tersaji perihal jumlah orang meninggal dunia yang tercatat pada dinas lingkungan hidup dirinci menurut agama di kota Makassar tahun 2016. 
Dari data olahan UPTD penempatan-penempatan blok-blok pemakaman menunjukan bahwa dari bulan januari sampai desember 2016 jumlah angka kematian ummat islam mencapai 2,665 jiwa dan umat kristen mencapai 463 jiwa dan lainlainnya mencapai 307 jiwa jika kita melihat data tersebut jumlah angka kematian umat islam lebih banyak dibandingkan dengan jumlah umat kristiani, jika kita hitung laju pertumbuhan angka kematian dari bulan januari sampai bulan desember sebanyak 3,435 jiwa. Dengan angka yang sangat signifikan ini dari tahun 2016 angka kematian sangat tinggi dari data inilah pemerintah harus mengambil peran yang tepat dalam pengambilan keputusan secara efektif.

Jika dilhat dari hasil wawancara peneliti, menunjukan bahwa untuk tercapainya penyediaan lahan yaitu, cara penertiban penempatan blok-blok pemakaman, yang kedua kebersihan, kemudian membentuk seperti taman hal ini diungkapkan oleh mandor pada pemakaman, menurut informan bahwa salah satu solusi tentang penyediaan lahan dengan mengatur pada area pemakaman namun pada solusi yang diberikan pada pengelola lahan ini apakah efektif atau tidak. Jalan yang paling baik adalah dengan melakukan perluasan lahan yang lebih luas lagi dari sebelumnya.

Dari pernyataan ini masyarakat berpikran bahwa bahwa menumpuk jenasah dalam satu liang kubur merupakan salah satu solusi yang tepat bagi mereka dikarenakan kurangnya ketersediaan lahan pada pemukiman lahan pemakaman, mungkin ini bisa menjadi suatu solusi yang tepat jika pemerintah tidak mampu mengambil langkah yang secara cepat dan tepat guna dalam permasalahan ini.

Peran Pemerintah Sebagai Fasilitator adalah menciptakan kondisi yang kondusif bagi pelaksanaan pembangunan untuk menjembatangi berbagai kepentingan masyarakat dalam mengoptimalkan pembangunan daerah. Sebagai fasilitator, pemerintah bergerak dibidang pendampingan melalui pelatihan, pendidikan, dan peningkatan keterampilan, serta 
dibidang pendanaan atau permodalan melalui pemberian bantuan modal kepada masyarakat yang diberdayakan.

Dari hasi wawancara peneliti menunjukan bahwa peran yang dilakukan kepala Dinas lingkungan hidup kota Makassar sebagai pemerintah dengan memfasilitasi lahan yang ada antara pemakaman ummat islam dan ummat kristen namun dengan hal ini walaupun pemerintah sebagai fasilitator, pemerintah yang terkait juga harus memperhitungkan ketersediaan lahan pada wilayah pemakaman pada wilayah Kota Makassar, pemerintah yang terkait harus mempunyai perencanaan-perencanaan yang jangka panjang dalam menagani dan mengurusi tentang masalah pemakaman karena jumlah angka kematian setiap harinya terus bertambah.

Berdasarkan penjelasan tersebut hal ini sesuai dengan komsep peranan pemerintah bahwa peranan merupakan penilaian sejauh mana fungsi seseorang atau bagian dalam menunjang usaha pencapaian tujuan yang ditetapkan atau ukuran mengenai hubungan dua variabel yang mempunyai hubungan sebab akibat. Dari penjelasan diatas dapat penulis simpulkan bahwa peran dalah suatu pola sikap, nilai dan tujuan yang diharapkan dari seseorang yang berdasarkan posisinya dimasyarakat. Sementara posisi tersebut merupakan identifikasi dari status atau tempat seseorang dalam suatu sistem sosial dan merupakan perwujudan dan aktualisasi diri. Peran juga diartikan sebagai serangkaian perilaku yang diharapakan oleh lingkungan sosial berhubungan dengan fungsi individu dalam kelompok sosial. Jadi dapat disimpulkan bahwa peranan pemerintah pada arah kebijkana memberikan solusi yang tepat sangatlah diperlukan.

Melihat permasalahan yang terjadi yang dihadapi pemerintah terkait tentang ketidak tersediaan lahan yang mau di bebaskan sehingga mempersulit pemerintah dalam memperluas wilayah pemakaman pada wilayah perkotaaan. Kita tau bahwa tujuan pengadaaan lahan bertujuan untuk 
pembangunan dan menyangkut pengaturan kembali penggunaan, pemanfaatan, pemilikan, dan penguasaan tanah sejalan dengan penatagunaan tanah. Selain itu juga bertujuan menghindari deskriminasi dan mencegah pemerkayaan diri melalui tindakan pemerintah.

Dari pernyataan ini perihal tentang kebijakan hal itu tentunya ketersediaan lahan pemakaman akan semakin sempit dari hari kehari melihat dari data sebelumnya angka kematian setiap harinya mencapai 20 orang jiwa dan dalam hiungan setahun mencapai 3,435 jiwa. Saya kira kebijakan ini kurang tepat dalam permaslahan ini pemerintah lebih berinovasi dalam menetukan suatu kebijakan yang harus sesuai dengan situasi keadaaan yang terjadi saat ini.

Dari hasil wawancara informan dengan indikator pemerintah sebagai fasilitator dalam penyediaan lahan pemakaman umum di kota Makassar hal ini dapat disimpulkan bahwa informan oleh mandor sebahai berikut pemakaman yang menyatakan bahwa sebenarnya sudah ada lahan yang disediakan di kelurahan manggala tetapi belum dibuka, salah satu faktor yaitu akses masuk sangat sulit untuk dijangkau karena masyarakat tidak mengizinkan lahannya untuk di jadikan jalan masuk kepemakaman.

Menurut penjelasan diatas menunjukan sudah ada tawaran solusi yang diberikan pada masyarakat wilayah perkotaan namun terdapat pula suatu permasalahan diantaranya akses yang sangat sulit, kemudian pihak masyarakat yang berda pada wilayah pemakaman yang nantinya dijadikan sebagai tempat pemakaman tidak menyetujui sehingga solusi yang ditawarkan pemerintah menjadi terhambat.

Dalam permasalahan ini perlunya pemerintah melakukan pendekatan-pendekatan kepada masyarakat setempat tentang perihal maslah ini supaya masyarakat mau memberikan akses nantinya. Tetapi dalam hal ini pemerintah juga harus melihat kriteria lokasi pemakaman dalam konteks tata ruang kota dalam konteks tata ruang kota, pengaturan lokasi pemakaman sebaiknya memperhatikan ukuran kota dan pembagian zona kotanya. Hal ini 
penting dilakukan mengingat lokasi pemakaman di dalam suatu zona kota akan berbeda kepentingan/fungsinya jika ukuran kotanya juga berbeda.

Dari hasil wawancara peneliti menunjukkan pemerintah sebagai fasilitator dengan memberikannya layanan kepada masyarakat berupa penyediaan ambulance serta tarif yang dikenakan dan berupa peralatan-peralatan yang lainnya yang digunakan dalam proses pemakaman, pemerintah sebagai fasilitator harus berperan aktif dalam memberikan pelayanan yang prima bagi masyarakat yang membutuhkan dalam hal ini tentang pelayanan pada penyediaan lahan pemakaman bagi warganya.

Dapat kita lihat bahwa peran pemerintah dalam hal ini sebagai pelayanan masyarakat dimana lebih mementingkan terpenuhinya kepuasan pelanggan (masyarakat), kaitannya dengan penyediaan lahan pemakaman di Kota Makassar pemerintah yang sebagai fasilitator wajib memberikan layanan yang penuh sesuai dengan standar yang dibutuhkan pada masyarakatnya.
Dari hasil wawancara peneliti menunjukan satu kesamaaan antara hasil wawancara kepala UPTD pemakaman dengan mandor bahwa pihak pemerintah memberikan layanan dengan memeberikan layanan berupa fasilitas ambulance bagi masyarakatnya yang membutuhkan, secara kesimpulan dapat simpulkan bahwa hal yang dilakukan oleh pemerintah dalam hal ini adalah memberikan pelayanan bagi masyarakatnya terkait dengan pengurusan pemakaman, kita tau bahwa dalam rangka pembangunan nasional, peran pemerintah tidak hanya melaksanakan tugas umum pembangunan melainkan yaitu mengarahkan, menggerakkan dan mengendalikan pembangunan secara lancar, serta meningkatkan peran aktif masyarakat dalam pembangunan.

Tujuan Pengadaan lahan bertujuan untuk pembangunan dan menyangkut pengaturan kembali penggunaan, pemanfaatan, pemilikan, dan penguasaan tanah (landreform) sejalan dengan penatagunaan tanah. Selain itu juga bertujuan menghindari diskriminasi 
dan (arbitrariness) mencegah pemerkayaan diri melalui tindakan pemerintah.

Dari penjelasan diatas tentang tercapainya penyediaan lahan pemakaman yang baik dikota Makassar secara kesimpulan dari kumpulan hasil wawancara bahwa pemerintah belum bisa memperluas wilayah pemakaman pada wilayah perkotaan dikarenakan tidak adanyanya lahan yang kosong untuk dijadikan tempat pemakaman umum namun, pemerintah terkait berupaya dalam mengatasi permasalahan tentang pemakaman yang terjadi di wilayah Kota Makassar. Namun disisi lain pemerintah sudah mampu memberikan berupa layanan yang dibutuhkan masyarakat ketika pengurusan pemakaman dengan memberikan fasilitas ambulance dan alat-alat yang dibutuhkan dalam proses pemakaman.

Dari hasil wawancara peneliti menunjukkan bahwa masyarakat wilayah perkotaan menginginkan adanya penambahan lahan pemakaman umum untuk warga kota Makassar sehingga permasalahan tentang pemakaman dapat teratasi, kita ketahui bahwa peran pemerintah disini sangat dibutuhkan ketika ada suatu permasalahan yang muncul dimana pemerintah yang terkait dapat menyelesaikan permasalahan dan mencarikan solusi yang tepat guna untuk menyelesaikan permasalahan-permasalahan yang terjadi saat ini.

Pemerintah yang terkait sudah berupaya dalam mengatasi tentang permasalahan lahan pemakaman di Kota Makassar kita ketahui sendiri bahwa banyak sumber masalahmasalah diantaranya semakin sempitnya area pemakaman jika dilihat dari data yang disajikan semua TPS di wilayah Kota Makassar sudah penuh, melihat penjelasan dari dinas lingkungan hidup kota Makassar sudah mengupayakan mencari solusi yang tepat dalam menindak lanjuti permasalahan tentang wilayah area pemakaman di Kota Makassar.

Kita tau sendiri sempitnya suatu pemakaman umum disebabkan Pertumbuhan penduduk yang semakin meningkat tentunya akan berdampak pada kebutuhan lahan 
sebagai tempat tinggal juga akan meningkat, perubahan yang terjadi tentunya berpengaruh pada ketersediaan lahan untuk tempat pemakaman umum. Dengan demikian pemerintah Kota Makassar mesti melakukan langkah antisipatif dalam menata wilayah perkotaan dengan baik. Pemakaman yang terletak di dalam sebuah Kota menjadi aset penting yang dapat menaikan mutu atau kualitas dari Kota tersebut. Pemakaman merupakan sebuah ruang terbuka hijau yang memberikan banyak keuntungan terutama bagi lingkungan sekitar tempat pemakaman tersebut berada. Jika melihat kondisi pemakaman yang terdapat pada daerah di Kota Makassar, maka kita akan melihat bahwa sebagian besar pemakaman tersebut kurang memiliki nilai estetika. Pada kenyataannya, pemakaman yang terdapat di daerah urban mempunyai fungsi khusus sebagai salah satu areal hijau dan resapan air yang dapat membantu mengurangi permasalahan seperti polusi udara yang dikeluarkan dari padatnya kendaraan bermotor di jalan raya dan bahaya banjir. Tetapi fungsi dari pemakaman tersebut belum terlihat dan dapat direalisasikan menjadi bagian dari kehidupan daerah urban seperti di Kota Makassar.

Selain itu bukan hanya denagan masalah sempitnya suatu lahan pemakaman tetapi Tempat pemakaman umum juga perlu ditata dan dikelola dengan baik maka akan berdampak positif bagi terpenuhinya kebutuhan masyarakat akan tempat pemakaman, tetapi sebaliknya apabila tempat pemakaman tersebut tidak ditata dan dikelola secara baik maka akan berdampak negatif bagi masyarakat seperti pencemaran lingkungan. Tempat Pemakaman Umum (TPU) merupakan sebuah kebutuhan masyarakat yang harus dipenuhi oleh Pemerintah khususnya di Kota Makassar. Kondisi TPU di Kota Makassar sudah sampai puncaknya, dilihat dari lahan untuk pemakaman sudah tidak lagi dapat menampung jenasah untuk dimakamkan. Untuk itu, penyediaan lahan yang sementara diproses oleh Pemerintah Kota Makassar dapat 
segera terealisasi, demikian pula dengan penataan dan pengelolaan TPU yang sudah ada maupun yang akan diadakan dapat dilakukan secara baik. Sehingga kebutuhan masyarakat dapat terpenuhi dan tidak lagi menimbulkan persoalan di masyarakat.

Secara kesimpulan bahwa pencapaian penyediaan lahan pemakaman pada wilayah kota Makassar belum tercapai sepenuhnya dengan baik karena lahan pemakan umum pada wilayah tersebut belum ada perluasan sehingga muncul beberapa permasalahan didalamnya melihat bahwa jumlah angka kematian dari tahun ketahun semakin meningkat jika pemerintah tidak mengambil langkah yang cepat maka penyempitan pada lahan semakin sempit.

\section{KESIMPULAN}

Peran pemerintah sebagai regulator yang menyebabkan terkendalanya penyediaan lahan pemakaman umum di kota Makassar yaitu: a. Pemerintah sebagai penentu Kebijakan pemerintah harus mampu membuat kebijakan yang dapat menjadi patokan dalam meningkatkan atau mengoptimalkan pengelolaan penertiban lahan pemakaman umum di setiap wilayah kota makassar. b. Mengupayakan Efisiensi dan Peningkatan Layanan. dalam mengupayakan efisiensi dan peningkatan pelayanan belum maksimal dan masih jauh dari harapan yang diinginkan, hal ini disebabkan karena penumpukan jenazah dengan keluarga yang sebelumnya yang meninggal sebagai ketetapan untuk mengefesiengkan lahan selain itu, pengadaan fasilitas maupun perbaikan fasilitas yang ada di Setiap pemakaman tersebut tidak terlalu diperhatikan 1. Peran pemerintah sebagai fasilitator dalam penyediaan lahan pemakaman umum di kota Makassar yaitu: a. Pemerintah sebagai penyedia lahan. perlunya penambahan lahan pemakaman untuk melayani jumlah penduduk yang meninggal di setiap tahunya semakin bertambah yang menjadikan di suatu wilayah pemakaman terjadi penumpukan jenazah.b. Pelayan pemerintah terhadap masyarakat. Pemerintah telah memfasilitasi lahan yang di 
kelolah yaitu pemakaman islam Dadi, Pemakaman islam Beroangin, Pemakaman islam Paropo, Pemakaman islam Sudiang raya, pemakaman Kristen Panaikang, dan Kristen Pannara. dan berupaya melakukan pelayanan dengan baik dengan penyediaan mobil Aambulace gratis untuk warga kota Makassar.

\section{DAFTAR PUSTAKA}

Bauer, Jeffery C. 2003. Role Ambiguity and Role Clarity: A Comparison of Attittudes in Germany and the United States. Dissertation, university of Cincinnati-Clermont.

Fadilah, Rifqah, 2014. Peran pemerintah Daerah Meningkatkan semangat Wirausaha Di Kelurahan Tettikendrarae Kecamatan Mariorwawo Kabupaten Soppeng. Universitas Muhammadiyah Makassar

Hutauruk, J.R. 2010. Isolasi senyawa flavonoida Dari Kulit Buah Tanaman Jengkol (pithecellobium lobatum Benth.) Skripsi, FMIPA,USU.77.

Mulyana, Asep Rahmat. 1994. Kriteria penyediaan lahan pemakaman umum di daerah perkotaan berdasarkan ukuran kota. Tugas akhir
Jurusan teknik Planologi ITB. Bandung.

Ndraha, Taliziduhu. 2003. Kybernology (ilmu pemerintahan baru) jilid 1. Jakarta: Rineka Cipta.

Nurcholis, Hanif. 2007. Teori dan Praktik: Pemerintahan dan Otonomi Daerah. Jakarta: Grasindo.

$$
\begin{array}{cr}
\text { Rizal,Muhammad,2014. } & \text { Peran } \\
\text { Pemerintah } & \text { Dalam } \\
\text { Meningkatkan } & \text { Produktivitas } \\
\text { Petani di } & \text { Desa Kanjilo } \\
\text { Kecamatan } & \text { Barombong } \\
\text { Kabupaten Gowa, Universitas } \\
\text { Muhammadiyah Makassar. }
\end{array}
$$

Soekanto, Soerjono. 2006. Sosiologi suatu pengantar ,PT. Raja Grafindo Persada, Jakarta

Sunarno, Siswanto, 2008, Hukum Pemerintahan Daerah Di Indonesia, Jakarta: Sinar Grafika Offset.

Tjandra, Riawan W, dkk. 2005. Peningkatan Kapasitas Pemda dalam Pelayanan Publik. Yogyakarta: Pembaruan. 